\title{
Influence of Selected Institutional Factors on the Impact of Constituency Development Fund in Financing Education in Public Secondary Schools in Ndaragwa Constituency, Kenya
}

\author{
Joseph Gicheru Ndei $^{1}$, John Kanjogu Kiumi ${ }^{1} \&$ Peter Githae Kaboro ${ }^{1}$ \\ ${ }^{1}$ Department of Curriculum and Education Management, Laikipia University, Kenya \\ Correspondence: Peter Githae Kaboro, Department of Curriculum and Education Management, Laikipia \\ University, Kenya.
}

Received: September 19, 2018

Accepted: October 26, 2018 Online Published: November 6, 2018

doi:10.20849/jed.v2i3.502

URL: https://doi.org/10.20849/jed.v2i3.502

\begin{abstract}
Access to secondary education in public secondary schools in Kenya has not been fully achieved due to rising costs in education. The Kenya government has therefore devised policies to help address issues of education access and retention through establishment of cost subsidies. The Constituency Development Fund (CDF) was established in 2003 through an Act of Parliament. The main objective was to mitigate the imbalance in regional development and provide people at the grassroots an opportunity to make expenditure choices that maximize their welfare in line with their needs and preferences. A key focus of CDF was to provide a devolved system of financing education. However, the extent to which CDF has succeeded in achieving this noble aim has not been evaluated. The focus of this study therefore was to find out the extent to which CDF as a means of financing education has succeeded in improving physical facilities, enhancing enrolment and reducing dropout rates in secondary schools in Ndaragwa Constituency, Kenya and to determine whether the impact is related to school type, enrolment, age and sponsorship. The study adopted an Ex-post facto research design where data were collected using self-administered questionnaires to 25 principals. Data were analyzed through descriptive and inferential statistics. Hypotheses were tested using ANOVA and t-test at an alpha level of 0.05 . The study established that there is no significant relationship between the impact of CDF in financing education and school type, enrolment, age and sponsorship. Based on the findings, the study recommends that CDF framework should be revised in order to assist schools to address pertinent issues facing them and to improve the quality of education in all secondary schools in Kenya.
\end{abstract}

Keywords: Constituency Development Fund (CDF), enrolment, financing education, school age, school sponsorship

\section{Introduction}

Education plays an important role in the entire development process of a country. Olaniyan and Okemakunde (2008) observed it is the human resource of a nation and not its material resources that ultimately determine the character and pace of economic and social development. Education is considered to be critical in the promotion of social, economic and political development. According to UNESCO (2002), education outcomes extend beyond individual and national income: it is a force that develops well-rounded and engaged citizens and builds more cohesive societies. In this regard it can be argued that increase in education will directly accelerate technological and hence economic progress of any nation. According to Kenya's National Report on the Development of Education of 2008, the main objective of the government of Kenya since independence in 1963 has been to provide quality education and training for all its citizens. However despite the immense benefits of education, Chiuri and Kiumi (2005) noted that it is an expensive venture. It therefore cannot be left either to individuals or the government alone to shoulder the full financial burden, but must be a shared venture of individuals, private and public companies, non-governmental organizations (NGOs) as well as the government itself.

Ever since the introduction of formal education in Kenya, various strategies have been initiated for financing it. According to Mutua (2009), public financing of education in Kenya started in 1909. Following the recommendations of Professor J. Nelson Fraser, experimental financial grants were made to mission schools. 
After independence in 1963, the Kenya government fully financed some of the secondary schools. However, due to the overwhelming demand for secondary education, the government allowed communities and religious bodies to set up their own schools. Some of these schools were partially funded by the government while others (referred to as Harambee schools) were purely financed by the parents. By 1968, these Harambee schools constituted 70 percent of all unaided secondary schools (Bogonko, 1994).

The government's implementation of the Structural Adjustment Programmes (SAP) package from the World Bank and International Monetary Fund (IMF) in 1986 saw a major shift in funding of education in Kenya. Kenya's National Development plan of 1989-1993 spelt out cost sharing arrangements in various public sectors including provision of education (Otiende, Wamahiu \& Karugu, 1992). From 1988 to 2007, secondary school education in Kenya was financed mainly through the cost sharing policy between the government, parents and communities. The government provided for teachers' salaries, curriculum development, bursaries and inspection/supervision services. Parents on the other hand provided teaching-learning materials, textbooks, physical infrastructure and other necessary direct costs to education such as uniforms, activity fees, private tuition charges and examination fees. At the same time, non-governmental organizations (NGOs) and the private sector contributed towards education through donations of funds and facilities, payment of school levies, especially in poor and marginal areas, scholarships and provision of bursaries (Abagi, 1997).

To cushion the poor and vulnerable groups against the adverse effects of cost sharing in education, the Kenya government through the Ministry of Education, Science and Technology (MOEST) introduced the bursary scheme in 2003. However, according to a study carried out by Njeru and Orodho (2003), the bursary fund was insufficient to meet the objectives of enhancing access to secondary school education and reducing dropout rate among the poor. This was because of the fact that the bursary kitty constituted only 6.4 per cent of the total outstanding costs. In 2008 the government started providing free day secondary education (FDSE) with a view to enhancing access to secondary education. Though there was a substantial increase in enrolment after implementation of FDSE programme, the 2009 Government of Kenya (GOK) Economic Survey noted that the cost of secondary education still remained prohibitively high due to boarding expenses which were not catered for by the grants allocated to the programme. This has led to more than half of the school age population not accessing secondary education (GOK, 2009).

The Constituency Development Fund (CDF) was established in 2003 through the CDF Act in the Kenya Gazette supplement No. 107 (2004). The main aim of the fund was to control imbalances in regional development and provide people at the grassroots with the opportunity to make expenditure choices that maximize their welfare in line with their needs and preferences (GOK, 2003). The projects that are funded through CDF are community based. This arrangement aims at ensuring that the prospective benefits are available to a wide cross-section of the inhabitants of a particular area (CDF Act, 2004). A minimum of 10 per cent of the constituency funds allocation is used for the education bursary scheme. The CDF Act establishes four committees to manage the fund. These include the National Management Committee (NMC) and the National Constituency Development Fund Committee (NCDFC) which are at the national level and the District Project Committees (DPC) and Constituency Development Committees which operate at the grassroots level. Beneficiaries of the CDF funding are community based development projects which ensures that the benefits are enjoyed by all people at the constituency level. Local communities identify projects according to their needs in such sectors as education, water, healthcare and infrastructure among others.

After Kenya promulgated the new constitution in 2010, some of the projects that were previously financed through CDF were transferred to the county governments that were established by the new constitution. Secondary education however remained a function of the national government. To avoid conflicts with the county governments, the CDF Act of 2004 was amended in 2015. In the amendment, CDF was renamed the National Government CDF (NG-CDF). All the national government functions were to be financed through the NG-CDF. Due to the rising cost of secondary education, the government in 2012 appointed a task force to look into the cost of secondary education in Kenya. The task force recommended that the responsibility of developing school infrastructure be transferred from the parents to grassroots CDF and county governments. Consequently, the ministry of education developed secondary schools' fees guidelines which removed the responsibility of financing future infrastructural projects from parents to CDF and other government financing mechanisms (GOK, 2015). This arrangement made secondary school principals to interact more directly with CDF in an effort to develop their schools.

Individual schools have their unique characteristics and hence might differ in their needs. However there are certain characteristics that could be similar. This means that the characteristics might affect the impact of CDF in financing education in schools in a different or consistent manner. In a study carried out by Rodgers (2007) on 
the impact of an initiative code named Project Lead the Way (PLTW), it was found that there was no significant difference based on the school size and the number of years that their schools had offered the project. However it was found that the project had a significantly higher impact to schools that had existed for more than five years compared to those with less than five years of existence. The findings imply that certain institutional factors could have an effect on the impact of financing of various aspects of education in schools. This research therefore set out to find out the impact of CDF in improving physical facilities, enhancing enrolment and reducing dropout rates in secondary schools in Ndarawa Constituency and to establish whether this impact is influenced by school type, size, age and sponsorship.

\section{Purpose}

The purpose of the study was to investigate the impact of CDF in financing secondary school education in Ndaragwa constituency, Kenya and to establish whether the impact could be related to the school type, enrolment, age and type of sponsorship.

\section{Objectives}

The study sought to achieve the following specific objectives:

i. To assess whether type of school has any influence on the impact of CDF as a means of financing secondary school education in Ndaragwa Constituency, Kenya.

ii. To determine whether school's level of enrolment has any influence on the impact of CDF as a means of financing secondary school education in Ndaragwa Constituency, Kenya.

iii. To investigate whether the school's age has any influence on the impact of CDF as a means of financing secondary school education in Ndaragwa Constituency, Kenya.

iv. To investigate whether the type of school sponsorship has any influence on the impact of CDF as a means of financing secondary school education in Ndaragwa Constituency, Kenya.

\section{Hypotheses}

The following null hypotheses were tested at an alpha level of .05:

$\mathrm{H}_{0} 1$ : Type of school has no statistically significant influence on the impact of CDF as a means of financing secondary school education in Ndaragwa Constituency, Kenya.

$\mathrm{H}_{0}$ 2: School enrolment has no statistically significant influence on the impact of CDF as a means of financing secondary school education in Ndaragwa Constituency, Kenya.

$\mathrm{H}_{0} 3$ : Age of school has no statistically significant influence on the impact of CDF as a means of financing secondary school education in Ndaragwa Constituency, Kenya.

$\mathrm{H}_{0} 4$ : Type of school sponsorship has no statistically significant influence on the impact of CDF as a means of financing secondary school education in Ndaragwa Constituency, Kenya.

\section{Methodology}

The study adopted the ex-post facto design. Ex-post facto design is used to determine the cause or consequence that exist between variables by observing an existing condition or state of affairs and search back in time for plausible causal factors (Kasomo, 2006). It is used to test a hypothesis about cause-effect or correlation relationships where it is not possible or ethical to apply experimental or quasi experimental design (Kothari, 2004). Consequently the effect of the independent on the dependent variable is determined retrospectively (Kerlinger, 1986). The design was adopted in view of the fact that CDF had been in place for several years before the study. Consequently the influence of how long the school has been in existence (school age), school enrolment, school type and school sponsorship on the impact of CDF in financing education was determined in situ meaning that the influence was investigated without manipulation or control. However, the study controlled the influence of the identified extraneous factors that included the length of time the principal had been in school management, the relationship between the principal and the CDF officials and availability of other sources of funding education in schools. The factors were controlled by including in the study, all the principals of day secondary schools in the Constituency. The variables subsumed in the study are represented in the conceptual framework illustrated in Figure 1: 


\section{Independent Variables $\quad$ Extraneous Variables Dependent Variables}

\begin{tabular}{|c|c|c|}
\hline $\begin{array}{l}\text { Selected school factors: } \\
\text { - } \quad \text { Type of school } \\
\text { - } \\
\text { - } \\
\text { Age of school } \\
\text { - } \quad \text { Lnrolment of the school } \\
\text { the school } \\
\text { - } \quad \text { School sponsorship }\end{array}$ & $\begin{array}{l}\text { - The length of time the } \\
\text { principal has been in school } \\
\text { management } \\
\text { - Relationship between the } \\
\text { principal and the CDF officials } \\
\text { - Availability of other sources } \\
\text { of funding }\end{array}$ & $\begin{array}{ll}\text { - } & \text { Impact of CDF as a means } \\
\text { of } & \text { financing secondary school } \\
\text { education: } \\
\text { - } \quad \text { Physical Facilities } \\
\text { - } & \text { Enrolment } \\
\text { - } & \text { Reducing Dropout Rate }\end{array}$ \\
\hline
\end{tabular}

Figure 1. Conceptualized interrelationship among variables of the study

The target population of the study comprised principals of day secondary schools in Ndaragwa Constituency. Principals were identified as the respondents of the study because they are the chief executive officers of their schools and they are expected to ensure and assure provision of adequate physical facilities of the schools as outlined in the Education Act of 2013. It is in the interest of the school principals to harness, utilize and maintain the physical infrastructure of their respective schools in order to meet the demands of their performance expectations. The principals are also expected to give technical advice to the school Boards of Management (BoMs) so as to promote the best interests of the institutions and ensure the institutions' development. For these reasons, principals were deemed to be best placed to provide the information that the study required. Fifty four (54) principals were randomly selected to take part in the study.

The study used a questionnaire to collect data. The questionnaire contained 30 Likert type items which were categorized into three sub-sections. Sub-section one collected data on the impact of CDF in financing physical facilities, section two focused on the role of CDF in improving enrolment while section three collected data on the extent to which CDF had contributed to the reduction of dropout rate in schools. The items had five response categories namely strongly agree, agree, undecided, disagree and strongly disagree. The responses categories were allocated scores of 5, 4, 3, 2 and 1 respectively. However, the scoring chart was reversed for negative statements. The questionnaire was systematically assessed for validity and reliability using data from a pilot study that involved 12 schools in the neighbouring Ol-joro-orok constituency. Data were analyzed using descriptive statistics specifically means and frequency counts. Hypotheses were tested using t-test and ANOVA at .05 level of significance.

\section{Findings and Discussion}

The research sought to establish the impact of CDF in financing three key areas in secondary school education. These areas formed the bases of the Likert scale type items and included improvement of physical facilities, enhancing enrolment and reduction of dropout rates in schools. The principals were asked to indicate their rating of CDF in these areas using the Likert scale items. The ratings by the principals were analyzed and the means scaled against four categories as illustrated in Figure 2:

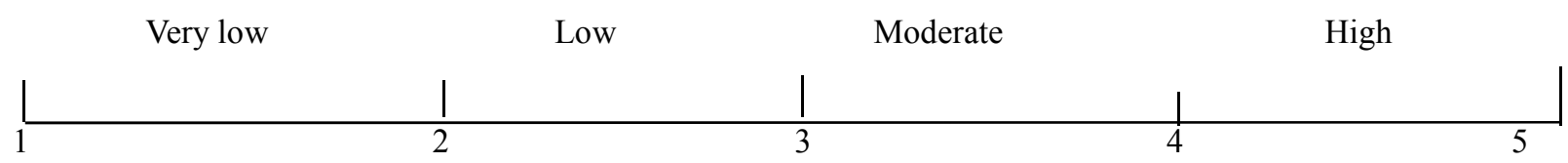

Figure 2. Distribution chart of principals' rating of CDF based on scores of likert scale items

According to Figure 2, a mean of less than 2 was categorized as very low between 2 and 3 as low, between 3 and 4 as moderate and above 4 as high.

\subsection{Impact of CDF on the Improvement of School Physical Facilities}

The study sought to find out the impact of CDF in financing specific physical facilities in schools. Principals were asked to indicate their rating with regard to the extent to which CDF had contributed to the improvement of 
specific physical facilities. The findings are presented in Table 1.

Table 1. Principals' rating of the impact of CDF in improvement of physical facilities

\begin{tabular}{cc}
\hline Item & Index \\
\hline Construction of additional classrooms & 3.00 \\
Acquiring computers & 2.41 \\
Construction an administration block & 2.27 \\
Improvement of sports equipment and facilities & 1.73 \\
Construction or Improvement of sanitary facilities & 2.23 \\
Power Connection & 2.23 \\
Improvement of Security & 1.91 \\
Facilitation of power supply & 1.90 \\
Acquiring of chairs & 1.75 \\
Improvement of teaching of science & 2.77 \\
Average & 2.22 \\
\hline
\end{tabular}

As clearly illustrated in Table 1, the principals rated the construction of additional classrooms highly. This could suggest that CDF responded well to the high demand for secondary education occasioned by the introduction of subsidized secondary education in 2008. This finding is consistent with findings of a study carried out by Mbaya and Maende (2014) in Sabatia Sub-county that found that CDF was one of the institutions that assisted schools in response to serious congestion in classrooms witnessed after the introduction of subsidized secondary education. This could also point to a deliberate effort by the government to improve transition rate from primary to secondary education.

Integrating ICT in teaching and learning is one of the strategies that the government is using to enhance quality of teaching and learning in schools. This requires that schools have reliable source of power, computers including other ICT equipment. Towards this end, CDF seems to fair poorly in both provision of computers and assisting schools to connect to the power grid. On electric power connection, the low rating could be attributed to the fact that the Kenya government is collaborating with Rural Electrification Authority (REA) which has seen 73.7 per cent of secondary schools being connected to the power grid as reported in the Basic Education statistical booklet of 2014. After being connected to the national grid, schools were expected to look for funds to finance wiring and other necessary equipments within the school. From the rating in table $12 \mathrm{CDF}$ appears not to have assisted schools in this area. Physical facilities such as administration block, chairs and sports facilities are crucial in making students and other school personnel comfortable and enjoy their stay in the school. Towards this direction, the principals appear not to be satisfied with what CDF has done in this area, thus the low rating.

According to Session Paper Number 10 of 2012 on Kenya vision 2030, Science Technology and Innovation (STI) will be critical to the socio-economic transformation of the country. In this regard improving the teaching of science subjects in schools will go a long way in equipping learners with basic skills that will enable them to pursue science based courses at the university. The principals' rating of CDF in this area appears to suggest that CDF has not played a significant role in assisting schools to improve on of teaching of science subjects. The principals' rating of CDF on improvement of security of their schools was low. It is worth noting that the safety of the learners is central in the provision of quality education in any county. This has been emphasized by the safety standards manual for schools of 2008. The low rating of CDF by the principals in this area could be due to the fact that the nature of insecurity challenges faced by schools includes cases that are mostly related to students' indiscipline as noted by Kaberia, Limukii, Ndiku and Mwaluko (2012). CDF therefore has minimal role to play in the maintenance of students' discipline.

\subsection{Impact of CDF in Improvement of School Enrolment}

Table 2 shows the distribution of principals' rating of the impact of CDF in improvement of aspects that contribute to enrolment in schools. 
Table 2. Impact of CDF in the improvement of enrolment as rated by the principals

\begin{tabular}{|c|c|}
\hline Item & Index \\
\hline Increased capacity to admit more students & 3.82 \\
\hline Bursary has helped students join Form 1 & 3.86 \\
\hline $\begin{array}{l}\text { School was able to admit students who had missed places in other school through } \\
\text { political conflicts }\end{array}$ & 2.91 \\
\hline Paid fees for students who would otherwise not have joined school & 3.27 \\
\hline Students who had not joined school in other years joined form one & 3.18 \\
\hline Offers financial assistance to students who are IDPs & 2.91 \\
\hline Used to pay fees for orphaned students through HIV/AIDs & 3.38 \\
\hline Students from physically/mentally challenged parents assured of CDF & 2.95 \\
\hline Students from families affected by natural calamities receive financial assistance & 2.95 \\
\hline Students rescued from various forms of abuse are assisted & 2.55 \\
\hline Average & 3.18 \\
\hline
\end{tabular}

The mean rating of the impact of CDF in the improvement of enrolment was 3.18 as shown in Table 2. This rating was high as per the rating scale and also the highest among the three categories. This high rating could be due to the fact that the CDF Act has set a limit of not more than 10 percent allocation of the CDF bursary scheme. The funds could be reaching more students because the 10 percent share has always been set aside for that specific purpose while physical facilities have to compete for funding with other community based projects.

However, a closer look at the data presented in Table 2 shows some disparities in the various groups that have been assisted by CDF towards improvement of school enrolment. While the rating of assisting students by CDF to join Form One is high at 3.86, vulnerable children from parents who were physically or mentally challenged, those whose parents may have been affected by natural calamities and those who had been rescued from various forms of abuse may have been neglected by CDF. It is worth noting that the schools' census conducted by the Ministry of Education found that approximately 12 percent of pupils in primary schools were orphaned and vulnerable children (OVC) and those in secondary schools constituted 2.9 percent. This shows that the transition rate to secondary school by OVC is very low compared to the national average. With a mean rating of $2.55,2.91$ and 2.95, it suggests that the awarding of CDF bursaries may not have been well distributed.

\subsection{Impact of CDF in Reduction of Dropout Rates in Schools}

Dropout rate was considered as the percentage of 16-24 year olds who are not enrolled in school. For the purposes of this study, a dropout was defined as any student who abandons school completely after being enrolled before sitting for Kenya Certificate of Secondary Education (KCSE) examination. The impact of CDF in the reduction of dropout rate was low at 2.41 as illustrated in Table 3.

Table 3. Impact of CDF on reduction of dropout rates in schools

\begin{tabular}{cc}
\hline Item & Index \\
\hline Maintains needy students joining form one until they finish form four & 2.95 \\
Emerging needy students are given CDF until they finish school & 2.68 \\
Amount of CDF given meets all fee requirements for needy students & 1.82 \\
Student who are given CDF are not sent home for fees & 2.59 \\
Timing of disbursement of CDF bursary enables students to remain in school throughout & 1.95 \\
the term & \\
\hline
\end{tabular}


Table 3 (continued). Impact of CDF on reduction of dropout rates in schools

\begin{tabular}{cc}
\hline Item & Index \\
\hline A significant number of needy students are maintained in school through CDF funding \\
CDF bursary is a reliable source of fees for needy students in my school & 2.50 \\
Students from parents who are unable to raise the required fees in the course of the students & 3.10 \\
studies in my school are assisted through CDF & 1.86 \\
Used to facilitate professional counselling of students in my school to Avoid dropping out & 1.82 \\
of school & 2.41 \\
\hline
\end{tabular}

For the various areas that can lead to students dropping out of school as presented in Table 3, the principals' ratings indicate that $\mathrm{CDF}$ has assisted students who become needy in the course of their secondary school education more than all the others. The reasons for dropping out of school are due to perceived future prospects or lack of them, schools failing to provide impetus for continued study, youngsters admiring the lifestyles of contemporaries who had already left, youngsters being tired of study and schools being no fun (Wambugu \& Makoena, 2013). In this regard dropping out of school can be mitigated through guidance and counselling and promoting co-curricular activities. This will accommodate students who are good in the co-curricular activities and thus they will enjoy their school life.

From the findings in Table 3, it can be noted that the principals' rating of CDF's effectiveness in assisting the schools to promote co-curricular activities and guidance and counselling programmes was very low. According to the findings, principals' ratings indicate that CDF is not a reliable source of funds in instituting measures aimed at reducing the dropout rates in secondary schools in Ndaragwa constituency, Kenya.

\subsection{Tests of Hypotheses}

The study also set out to find out whether the impact of CDF in financing education as rated by the principals was influenced by the institutional factors of school type, size, age and sponsorship. Consequently, four hypotheses were formulated for testing. The first hypothesis postulated that the school type had no statistically significant influence on the impact of CDF as a means of financing secondary education in Ndaragwa Constituency. In order to test the hypothesis, the mean scores of the principals' ratings based on type of school were computed. The results are presented in Table 4.

Table 4. Principals' mean rating of CDF as a means of financing education by type of school

\begin{tabular}{lcccc}
\hline School Type & $\mathrm{N}$ & Mean & STD. Deviation & STD. Error \\
\hline Boys' Boarding & 2 & 2.0667 & .09428 & .06667 \\
Girls' Boarding & 3 & 2.6395 & .99381 & .57378 \\
Mixed Day & 17 & 2.6606 & .36215 & .08783 \\
Total & 22 & 2.6037 & .47400 & .08783 \\
\hline
\end{tabular}

A scrutiny of the data in Table 4 shows that the highest rating of CDF was by principals of mixed day schools $($ mean $=2.660)$ followed by those in girls boarding schools $($ mean $=2.639)$. The lowest rating was by principals of boys boarding schools (mean = 2.066). It is worth noting that the mean score of boys boarding was lower compared to that of both mixed day schools and girls boarding. This observation seems to suggest that the probability of CDF being rated highly by principals may be influenced by the type of school. This finding may be rooted in the fact that CDF may finance mixed day schools more than boarding schools possibly due to increased demand for secondary education as a result of the introduction of free day secondary education by the government in 2008. Girls boarding schools may be receiving higher financing from CDF due to affirmative action promoted by the Kenya government in order achieve gender parity in access to secondary education. It could also be argued that $\mathrm{CDF}$ is making an effort to meet the demands of the constitution which expresses that 
state organs and public officers have a duty to address the needs of vulnerable groups including women (GOK, 2010). This finding also supports the findings by EFA (2012) that the reasons for the impressive female enrolment in secondary schools meant that strategies being applied are arguably working well in encouraging the access and participation of female students at the secondary school level.

In order to establish whether the differences in mean scores noted in Table 4 were statistically significant, ANOVA tests of significance were carried out. The results of the test are displayed in Table 5.

Table 5. ANOVA test of significance of the differences between means of the principals' rating of the impact of CDF in financing education by type of school

\begin{tabular}{lccccc}
\hline Source of Variation & sum of squares & $\mathrm{df}$ & Mean Square & $\mathrm{F}$ & p-value \\
\hline Between groups & .636 & 2 & .318 & 1.479 & .253 \\
Within groups & 4.083 & 19 & .215 & & \\
Total & 4.718 & 21 & & & \\
\hline
\end{tabular}

The data displayed in Table 5 shows that the differences in principals' mean scores noted in Table 4 were not statistically significant $(\mathrm{p}>.05)$. In order to find out whether there was any significant difference between the means of any pair of the groups, Tukey-Kramer post hoc tests were carried out. The results of the tests are displayed in Table 6.

Table 6. Pair-wise comparison of group means of principals' ratings by type of school using post hoc tests

\begin{tabular}{lcc}
\hline Pair & Means Difference & p-Value \\
\hline Boys Boarding Vs Girls Boarding & .5728 & .197 \\
Boys Boarding Vs Mixed Day & .5939 & .202 \\
Girls Boarding Vs Mixed Day & .0211 & .232 \\
\hline
\end{tabular}

The data in Table 6 indicates that none of the differences of the paired group means were statistically significant. Consequently hypothesis $\mathrm{H}_{0} 1$ was not rejected and a conclusion was made that the impact of CDF in financing secondary school education in Ndaragwa Constituency was independent of the type of school.

The second hypothesis proposed that the size of the school in terms of enrolment had no statistically significant influence on the way principals rated CDF as a means of financing secondary school education in Ndaragwa constituency. In order to establish the validity of this assumption, the mean scores of the principals' rating of $\mathrm{CDF}$ as a means of financing secondary education based on the level of school enrolment were computed. The results are presented in Table 7.

Table 7. Principals' mean rating of CDF as a means of financing secondary education based on school enrolment

\begin{tabular}{lcccc}
\hline School Enrolment & $\mathrm{N}$ & Mean & STD. Deviation & STD. Error \\
\hline $0-250$ & 9 & 2.6656 & .53194 & .17731 \\
$251-350$ & 3 & 2.6889 & .39487 & .22798 \\
Above 350 & 8 & 2.5239 & .53121 & .18781 \\
Total & 20 & 2.6124 & .49506 & .11070 \\
\hline
\end{tabular}

A scrutiny at the data in Table 7 reveals that the highest rating of CDF was by principals' whose schools' enrolment ranged between 251 and 350 (mean $=2.688$ ), followed by principals in schools whose enrolment ranged between 0 and 250 (mean $=2.665$ ) and lastly principals of schools with an enrolment of 350 and above (mean $=2.523$ ). Schools with an enrolment of 251 to 350 are likely to be transiting from single stream to double stream going by the recommended class size of 45-50 students. CDF could therefore be giving the schools preference in a bid to increase access to secondary education. The schools with an enrolment of 0 to 250 are likely to be newly established schools that may be in the process of establishing basic infrastructure. CDF is 
therefore likely to be financing the schools to boost the level of access to education. The low rating by principals of schools with an enrolment of above 350 could be due to the fact that while the cost of acquiring an item or putting up a building could be the same irrespective of the enrolment, the unit cost per student in schools with a higher enrolment will be lower compared to those with low enrolment. Therefore principals with enrolments above 350 could be relying less on CDF due to availability of alternative sources of finances possibly from development levy charged by schools with approval of the county education boards.

To establish whether the difference in ratings was significant, ANOVA test of statistical significance was carried out. The results of the test are presented in Table 8 .

Table 8. ANOVA test of significance of the difference between means of principals' rating of CDF based on school enrolment

\begin{tabular}{lccccc}
\hline Source of variance & Sum of Squares & $\mathrm{df}$ & Mean Square & $\mathrm{F}$ & Sig. \\
\hline Between groups & .606 & 2 & .053 & .198 & .823 \\
Within groups & & 17 & .268 & & \\
Total & 4.657 & 19 & & & \\
\hline
\end{tabular}

The data presented in Table 8 indicates that the mean ratings of principals of schools with different levels of enrolment were not significantly different $(p>.05)$. In order to find out whether there was any significant difference between the means of any pair of the groups, Tukey-Kramer post hoc tests were carried out. The results of the tests are displayed in Table 9.

Table 9. Pair-wise comparison of group means of principals' ratings based on school enrolment using Post Hoc Tests

\begin{tabular}{ccc}
\hline Pair & Means Difference & p-Value \\
\hline $0-250$ and 251-350 & .0233 & .247 \\
$251-350$ and Above 350 & .1650 & .194 \\
$0-250$ and Above 350 & .1317 & .211 \\
\hline
\end{tabular}

The data in Table 9 indicates that none of the differences of the paired group means were statistically significant. Consequently hypothesis $\mathrm{H}_{0} 2$ was retained and conclusion made that principals' rating of the impact of CDF in financing education in Ndaragwa Constituency was not influenced by the size of the school. These findings are consistent with those of Teahon (2012) who found that school enrolment had no significant influence on the principals' rating of programmes dubbed STARS and NESA on their influence in the implementation of a balanced assessment system in Nebraska.

The third hypothesis expressed that the age of the school had no statistically significant influence on principals' rating of $\mathrm{CDF}$ as a means of funding secondary school education in Ndaragwa Constituency. In order to investigate the validity of this presumption, the difference between means of the principals' ratings based on school age were tested for statistical significance. The mean ratings are displayed in Table 10.

Table 10. Principals' mean rating of CDF as a means of financing secondary education based on age of school

\begin{tabular}{lcccc}
\hline School Age & $\mathrm{N}$ & Mean & STD. Deviation & STD. Error \\
\hline $1-5$ years & 3 & 2.5747 & .50247 & .29010 \\
$11-15$ years & 4 & 3.0250 & .49768 & .24884 \\
Above 15 years & 15 & 2.4972 & .42991 & .11100 \\
Total & 22 & 2.6037 & .47400 & .10106 \\
\hline
\end{tabular}

A close inspection of the data in Table 10 reveals that the principals of schools established 11-15 years ago rated 
CDF more favourably compared to those in schools established 1-5 years ago and those established more than 15 years ago. It is worth noting that the establishment of schools in the 11-15 years category coincided with the establishment of CDF. There is a high probability that these schools were started through CDF. It is also likely that there could be several completed projects and other learning resources in these schools which could be attributed to CDF. Schools established more than 15 years ago may have financed their development through the sources that were available before the establishment of CDF. The low rating by principals in these schools could be due to the fact that they already had their basic infrastructure by the time of implementation of the CDF Act and therefore CDF may have given the younger schools more priority compared to the older schools. ANOVA test of significance was carried out to test the significance of the observed differences. The results of the test are presented in Table 11 .

Table 11. ANOVA test of significance of the difference between means of the principals' rating of CDF in financing education by school age

\begin{tabular}{lccccc}
\hline Source of Variance & Sum of Squares & df & Mean Square & F & sig. \\
\hline Between groups & .883 & 2 & .441 & 2.186 & .140 \\
Within groups & 3.836 & 19 & .202 & & \\
Total & 4.718 & 21 & & & \\
\hline
\end{tabular}

The data in Table 11 indicates that the mean ratings in Table 10 were not significantly different $(\mathrm{P}>.05)$. Further, post hoc tests were carried out to establish whether there was any significant difference between any pair of the group means. The results of the Tukey-Kramer post hoc tests are displayed in Table 12.

Table 12. Pair-wise comparison of group means of principals' ratings by age of school using post hoc tests

\begin{tabular}{ccc}
\hline Pair & Means Difference & p-Value \\
\hline $1-5$ and 11-15 years & .4503 & .107 \\
$1-5$ and above 15 years & .0775 & .095 \\
$11-15$ and above 15 years & .5278 & .188 \\
\hline
\end{tabular}

A scrutiny of the results in Table 12 shows that there was no statistically significant difference between any pair of the means of principals' ratings based on the age categories of the schools. Based on these observations, $\mathrm{H}_{0} 3$ was retained and a conclusion made that school age had no statistically significant influence on principals' rating of the impact of CDF as a means of school funding in secondary schools in Ndaragwa Constituency. This finding concurs with the findings of a study by Blake (2016) that found that the time schools had been offering the JROTC programme had no significant influence of the principals' rating of the effectiveness of the programme.

The fourth hypothesis postulated that schools' sponsorship had no statistically significant influence on the principals' rating of the impact of CDF as a means of financing secondary school education in Ndaragwa Constituency. To investigate this presumption, independent samples t-test was performed with a view to establishing whether principals of schools sponsored by churches and those of schools sponsored by the government rated CDF significantly differently or not. The mean ratings are displayed in Tables 13:

Table 13. Principals' Mean perception scores based on school sponsors

\begin{tabular}{lcccc}
\hline School Sponsors & $\mathrm{N}$ & Mean & STD. Deviation & STD. Error \\
\hline Government of Kenya & 10 & 2.6860 & .44180 & .1397 \\
Church & 12 & 2.6246 & .42219 & .1273 \\
\hline
\end{tabular}

An examination of the data displayed in Table 13 clearly shows that the mean ratings of principals from government sponsored schools and those from church sponsored schools were very close though principals of government sponsored schools rating was slightly higher than that of the principals form church sponsored 
schools. To determine whether or not the two mean ratings were significantly different, t-test analysis was carried out. The results are displayed in Table 14:

Table 14. Independent samples t-test of significance of the difference between means of the principals' rating of CDF in financing education based sponsorship of the school

\begin{tabular}{ccccccc}
\hline Levene's test for Equality of variances (2-tailed) Difference & $\mathrm{F}$ & $\mathrm{Sig}$. & $\mathrm{t}$ & $\mathrm{df}$ & sig. & Mean \\
\hline Equal variances assumed & .029 & .867 & .326 & 19 & .748 & .06142 \\
Equal variances not assumed & & & .325 & 18.605 & .749 & .06142 \\
\hline
\end{tabular}

The data shown in Table 14 indicates that the difference in mean ratings of principals from church sponsored schools and those from government sponsored schools was not statistically different $(t=0.326, p>.05)$. In view of this observation, the null hypothesis could not be rejected and a conclusion was therefore made that the sponsorship of the school and the principals' rating of the impact of CDF in financing secondary school education were statistically independent.

\section{Conclusions}

Based on the foregoing findings it can be concluded that the impact of CDF in financing secondary school education is generally low. The study established that other than improving on enrolment, CDF fared poorly in improvement of school physical resources and reducing dropout rates. This indicates that there is need for policy makers and education planners to develop a more effective framework for implementing CDF in schools. The results further indicate that institutional factors of type, age, size and sponsorship have no influence on the impact of CDF in financing secondary school education in Ndaragwa Constituency.

\section{Recommendations}

Based on the study findings, the following recommendations were made;

i. The government, in an endeavour to improve on retention and minimize school dropout could consider increasing the amount of funds set aside for CDF bursary. This will enable CDF to pay school fees for the applicants throughout the four years of secondary education rather than the current set up where the bursaries awarded to needy students are not guaranteed throughout their study period.

ii. In line with the proposed competency based curriculum in Kenya, CDF should consider assisting schools to improve co-curricular activities. This will not only help to nurture the talents of the students but will also help motivate and thereby retain students in schools.

iii. CDF should set aside funds to help the existing schools to increase their capacity to admit more students rather than set up new schools with few students. It could also consider assisting day schools to set up boarding sections so as to admit students from areas that are far from the school. This will help increase the school enrolment especially in rural and marginal areas.

\section{References}

Abagi, O. (1997). Public and Private Investment in Primary Education in Kenya: An Agenda for Change. Nairobi: Institute for Policy Analysis and Research.

Blake, J. (2016). Principals' Perceptions of the Effectiveness of JROTC Programme (PhD thesis). South Africa: University of Cape Town.

Bogonko, S. N. (1992). A History of Modern Education in Kenya 1895-1991. Nairobi: Oxford University Press.

Chiuri, L.W., \& Kiumi J. K. (2005). Planning and Economics of Education. Pangolin Publishers Ltd.

Education for All. (EFA). (2012). Assessment of Progress. Kenya Country Report August 1999. Effectiveness of Kenya Education Bursary Scheme, l12(1). Retrieved from http://www./par.Or.Ke/Documents/.../PARPolicyBrief

Government of Kenya. (2003). National Development Report 2002 - 2008. Nairobi: Government Printer.

Government of Kenya. (2004). Economic Survey 1989. Nairobi: Government Printer.

Government of Kenya. (2005). Nyandarua District Strategic Plan 2005-2010. National coordination Agency for Population and Development, Ministry of Planning and National Development. Chancery Tower Valley 
Road, Nairobi.

Government of Kenya. (2008). Economic Survey 2007. Nairobi: Government Printer.

Government of Kenya. (2010). Economic Survey (2009). Nairobi: Government Printer.

Government of Kenya. (2013). The Basic Education Act (2013). Nairobi: Government Printer.

Government of Kenya. (2015). Fees guidelines for public secondary schools (2015). Nairobi: Government Printer.

Government of Kenya. (2015). Fees guidelines for secondary schools in Kenya (2015). Nairobi: Government printer.

Government of Kenya. (2015). The National Government Constituencies Development Fund Act (2015). Nairobi: Government printer.

Kaberia, E., Limukii, O., Ndiku, F., \& Mwaluko, J. (2012). The Free Education Policy in Kenya: A Critique. International Journal of Education Administration and Policy Studies, 14, 23-40.

Kasomo, D. (2006). Research Methods in Humanities and Education. Kenya: Egerton University Press.

Kerlinger, F. N. (1986). Foundations of Behavioral research (2nd ed.). New Yolk: Holt Reinhrt and Wilson.

Kothari, C. R. (2004). Research Methodology. Methods and Techniques (2nd ed.). New Weley Eastern LTD 2009.

Mbaya J. B., \& Maende J. T. (2014). Impact of Subsidized School Funding on Infrastructure Development in Public Secondary Schools in Sabatia Sub County, Vihiga County, Kenya (MED Thesis). Mount Kenya university.

Ministry of Education. (2003). National Report on the Development of Education in Kenya 2001. Nairobi: Government Printers.

Mutua, R. W. (2009). Development of Education in Kenya 1946 -1963. Nairobi: East African Literature Bureau.

Njeru, E. H., \& Orodho, J. A. (2003). Education Financing in Kenya. Secondary schools Bursary Scheme; Implementation and Challenges. Nairobi: IPAR.

Olaniyan, D. A., \& Okemakinde, P. K. (2008). Human Capital Theory Implications for Educational Development. Retrieved from http://www.Eurojournals.com/Ejsr.24-201

Otiende, J. E., Wamahiu, S. P., \& Karugu, A. M. (1992). Education and Development in Kenya: A Historical Perspective. Nairobi: Oxford University Press.

Rodgers, G. E. (2007). Perceptions of High School Principals Related to Project Lead The Way. Purdue University. Journal of Industrial Teachers Education, 44(1).

Teahon, M. D. (2012). Perceptions of Nebresca Administrators Regarding Transition from NeSA and its Perceived Influence of Implementation of as Balanced Assessment System. Lincoln Nebreska University.

UNESCO-UIS. (2002). Financing Education in Sub-Saharan Africa. Meeting the Challenges of Expansion, Equity and Quality. Montreal Quebec, Canada: UNESCO Institute of Statistics.

Wambugu, J., \& Makoena, S. (2013). Education Financing in Kenya: Parents' Perceptions about Implementation of Cost Sharing Policy in Secondary Education. Mediterranean Journal of Social Sciences, 4(13), 12-28. https://doi.org/10.5901/mjss.2013.v4n13p441

\section{Copyrights}

Copyright for this article is retained by the author(s), with first publication rights granted to the journal.

This is an open-access article distributed under the terms and conditions of the Creative Commons Attribution license (http://creativecommons.org/licenses/by/4.0/). 